\title{
THE FORMATION OF TEACHERS' MEDIA COMPETENCIES AS A PROBLEM OF MODERN PEDAGOGY
}

\begin{abstract}
In the $21^{\text {st }}$ century, modern society learns and lives by new rules and laws. They are dictated by the surrounding reality. If education is cut off from modern life, then it can not be of interest to the pupils, which would make it ineffective. The introduction of information technologies is one of the keys to organizing effective education for pupils. Therefore, the role of the teacher in this process is extremely important.

Teacher's media competencies are aimed at pupils' correct selection and interpretation of media content, their perception and understanding of the content, avoiding manipulation, and literate media use.

Our research among learners, teachers, parents shows that the use of media in modern school is not widespread. Teachers rarely use media technologies during lessons and, as a rule, they are not aimed at the development of the pupils' media literacy, but act as meeting the demand of applying innovative methods and technical means.

In order to organize children's media education, to use media tools, to identify teachers' level of media literacy and to develop media competencies, studies have been conducted in various secondary schools. The studies show that some teachers don't know exactly what the media is. The responses of some of the teachers who participated in the survey show that teachers do not exactly understand the nature of the media, the forms, the answers of many of them are different and incomplete. Teachers are mostly unaware of media technologies and do not realize its role in the upbringing and development of children.

Summing up the results of surveys of teachers, children and their parents, we came to the conclusion that the central role in the implementation of media education is played by the teacher. He is the pedagogue of ICT and the media the one who carries out parental education; he is the one who turns students into media educators. So it is necessary to help the teacher and the future teachers in carrying out their mission.

All this forced us to try to develop the following media competencies of teacher and in parallel, determine the pupil's media competencies.
\end{abstract}

\section{Keywords:}


Media competence, media literacy, media technology, innovative pedagogical process, parental education

\section{Introduction}

Effective organization of educational process at school from the modern teacher required a number of competencies in which media competence is unique.

In the $21^{\text {st }}$ century, modern society learns and lives by new rules and laws. They are dictated by the surrounding reality. If education is cut off from modern life, then it can not be of interest to the pupils, which would make it ineffective. The introduction of information technologies is one of the keys to organizing effective education for pupils. The child is an active consumer of verbal and audiovisual forms (text, audio, animation, video, images, web, etc.), media content. However, he is often unaware of their content and impact on the formation of its outlook and the formation of its personality. Therefore, the role of the teacher in this process is extremely important.

Teacher's media competencies are aimed at pupils' correct selection and interpretation of media content, their perception and understanding of the content, avoiding manipulation, and literate media use.

Our research among learners, teachers, parents shows that the use of media in modern school is not widespread. Teachers rarely use media technologies during lessons and, as a rule, they are not aimed at the development of the pupils' media literacy, but act as meeting the demand of applying innovative methods and technical means.

There are different approaches to the term "media competence" in science. In Germany, for example, it's referred to as "the ability of a person to show qualified, independent, creative and social responsibility to the media". [Tulodziecki, 1997, p.120] This quote contains all the essentials of a teacher working with media. In another quote on the concept of "media competence" by R. Kubey, media competence and media literacy are combined. That is, "being able to apply, analyze, evaluate and transmit media messages in different ways [Kubey, 1997, p.2].

Russian literature also uses the term "media education", which combines the concepts of media literacy and media competence. In particular, N.V. Zmanovskaya interprets it as "a set of media literacy, abilities and a value attitude towards it, as well as a certain level of mastery of students' media education implementation in the pedagogical process. [Zmanovskaya, 2004, p.10].

Thus, a teacher's media competence can be characterized as a unity of motives, knowledge, abilities, abilities, skills, and values, which facilitates the selection, application, 
examination, evaluation, and creation of media of various forms, genres, types of media content, media contexts during educational activities.

\section{Materials and methods}

In order to organize children's media education, to use media tools, to identify teachers' level of media literacy and to develop media competencies, studies have been conducted in various secondary schools in Yerevan. 113 teachers participated in the survey. The results of the study allowed us to reveal the following facts.

Some teachers don't know exactly what the media is. The responses of some of the teachers who participated in the survey show that teachers do not exactly understand the nature of the media, the forms, the answers of many of them are different and incomplete.

Most teachers also do not value the importance of the role of the media in the child's educational process. Many believe that child upbringing is carried out in a family and school where the media has no place (48,6\% of respondents think so), few of them emphasized the role of the media in child upbringing $(27,8 \%)$. The other teachers mentioned that the role of the media is insignificant. In fact, today there is a pedagogical community that does not understand the role of the media in the upbringing of children, without realizing that its role in the child's life is very large and uncontrollable. Moreover, not all teachers realize that they have ceased to be the only source of information, and in the face of computers, media, and ICT, they have a powerful and large competitor whose influence is hidden and unpredictable.

Many modern teachers do not realize the necessity of media education. The majority of the teachers participating in the survey (59.8\%) believe that media education should only be provided through optional courses. This group finds that the modern school curriculum is already overloaded with various subjects. Therefore the integration of media into all subject courses will cause unnecessary workload for both teachers and learners. Furthermore, $15,2 \%$ of the teachers participating in the survey which are strongly against media education. They find that it's inappropriate to implement in elementary school. These responses prove that the modern teachers' collective attitude towards the media is due to their low level of media literacy which leaves the child alone against the potentially harmful effects of this phenomenon.

Nevertheless, teachers' responses state that some of them actively use in a professional activity such media tools as video, cartoon (42,6\%), use of internet resources $(41,3 \%)$, and social networking opportunities (16,1\%). No teacher mentioned that he would give up the media tools. However, their answers reveal the fact that for many of the media tools use is just a way of organizing an innovative pedagogical process in class, but not a 
means of developing students' media literacy.

Moreover, teachers do not understand the role of the media in the upbringing of the child. For example, only 11 per cent of them mentioned that media could influence a child's aesthetic upbringing, perception of beauty, and media culture. In their opinion, the aesthetic taste of children, the perception of beauty is formed more through the teaching of schoolbased subjects, extracurricular activities, organizing excursions, visiting museums. Many of them do not feel that there is a need for media culture today. The majority of teachers (approximately 50 per cent) do not even consider the role of the media in the formation of students' critical thinking. Only $22-8 \%$ of them agree that media education definitely develops students' critical thinking skills.

Interestingly, 38\% of teachers find that modern school and educator are partially able to offset the negative impact of the media field on children, as children are not always under their control. $30 \%$ of educators are convinced that educators are "equipped" with the appropriate competencies and that the education system is fully prepared to neutralize the negative effects of the media. And only $32 \%$ of teachers realize that the modern school and pedagogue do not have enough knowledge to help neutralize the negative impact of the media field on the child, so the teacher needs support, professional advice.

Many teachers have cited their own example $(29,4 \%)$ as a means of neutralization of negative media impact on students, $31,6 \%$ of educators have cited the explanation of how to distinguish the good from the bad. $15-4 \%$ of the teachers who participated in the survey were not oriented and could not answer what to do in such cases. They find that the means of protection from these media threats do not fall into their professional competence and responsibility.

According to $32,6 \%$ of the respondents, the modern educator is capable of distinguishing between useful and inappropriate information from the media, as the modern educator communicates with the media field in everyday life and is already skilled in the process. $41.3 \%$ think that modern educators have some disadvantages in this field because they lack relevant knowledge, are not equipped with the tools to differentiate the fine distinction between misinformation and information, and $26.1 \%$ find that they are definitely not capable, as information flows are increasing day by day, and quickly navigating those streams is a rather complicated process that requires additional professional knowledge and skills.

Interestingly, only $18.7 \%$ of educators find that a modern educator can be media carrier and create media content, that is, take advantage of modern media and internet technologies. $46,9 \%$ think they do not have enough knowledge and skills to become a media 
carrier.

Thus our studies revealed that in order to make media an important part of the learning process, the school and teacher need comprehensive support. It is necessary to organize teacher training/43,8\%/, develop methodological guarantees $/ 36,9 \% /$, to enrich the material and technical base of schools by creating a media classroom at school with appropriate equipment and specialists $/ 19.3 \%$, and to implement media education for future teachers in the field of professional education $/ 98 \%$ / by arming them with appropriate competencies, realizing its need and the appropriate need.

Responses to parents' surveys confirm that most parents do not have the ability to sense information, orient themselves in the information field, respect the rules of netiquette and help children with these issues. Therefore, it is necessary to organize parental education courses in each school.

Those children's answers were disturbing wich prove that:

- our pupils are highly dependent on ICT;

- $\quad$ are left alone on social networks, due to lack of parents' time the rules and time for using the computer are not maintained;

- children feel defenceless in a conflicting information field and need the help of adults, which is often not provided.

\section{Results}

Summarizing the results of the surveys conducted among teachers, children and their parents, we came to the conclusion that the teacher plays a central role in the process of media education. The teacher is the one who enters ICT and media in the field of pedagogy. Therefore, it is necessary to assist the teacher and future teachers in fulfilling their mission.

All this made us try to develop the following media competencies of the teacher and in parallel to determine the pupil's media competencies.

\begin{tabular}{|c|c|c|c|}
\hline $\mathrm{N}$ & $\begin{array}{l}\text { Teacher's } \\
\text { competence }\end{array}$ & Description & Pupil's competence \\
\hline 1. & $\begin{array}{l}\text { - Understands } \\
\text { the role of the media } \\
\text { in the development } \\
\text { of the person, the } \\
\text { education and } \\
\text { training of the } \\
\text { generation. }\end{array}$ & $\begin{array}{l}\text { - Familiar with all } \\
\text { types of media, able to } \\
\text { use them in teaching and } \\
\text { extracurricular processes } \\
\text { and for various purposes. }\end{array}$ & $\begin{array}{l}\text { - Realizes that media } \\
\text { education is a right, an } \\
\text { opportunity for development, a } \\
\text { means of communication and } \\
\text { self-expression. }\end{array}$ \\
\hline
\end{tabular}




\begin{tabular}{|c|c|c|c|}
\hline 2. & $\begin{array}{l}\text { - Recognizes } \\
\text { the need for double } \\
\text { competence. }\end{array}$ & $\begin{array}{l}\text { - Constantly } \\
\text { engaged in self- } \\
\text { education, improving his } \\
\text { knowledge of ICT and } \\
\text { media education. }\end{array}$ & $\begin{array}{l}\text { - Has the need and } \\
\text { motivation to develop media } \\
\text { education. }\end{array}$ \\
\hline 3. & $\begin{array}{l}\text { - Creates } \\
\text { conditions and } \\
\text { opportunities for } \\
\text { learners to become } \\
\text { media carrier and } \\
\text { media creator. }\end{array}$ & $\begin{array}{l}\text { - Creates equal } \\
\text { conditions for everyone's } \\
\text { development, an } \\
\text { atmosphere of tolerance, } \\
\text { empathy, respect, } \\
\text { freedom, creativity and } \\
\text { initiative. } \\
\text { - Creates media } \\
\text { context with pupils } \\
\text { according to age and } \\
\text { experience, teaches to } \\
\text { differentiate between the } \\
\text { author's objective and } \\
\text { subjective approaches } \\
\text { (author's modality). } \\
\text { - Develops pupils' } \\
\text { analytical, comparative, } \\
\text { and critical thinking skills. } \\
\text { - Teaches to take into } \\
\text { account the audience } \\
\text { (mass or professional) } \\
\text { while writing the text, to } \\
\text { choose the means of } \\
\text { dissemination: } \\
\text { newspaper, school radio, } \\
\text { children's TV program, }\end{array}$ & $\begin{array}{l}\text { - Realizes, feels, sees the } \\
\text { opportunities and conditions } \\
\text { which are set to become a } \\
\text { media carrier and media } \\
\text { creator. Develops its creative, } \\
\text { critical thinking. } \\
\text { - Manifests itself as tolerant } \\
\text { of the opinions of others learns } \\
\text { to empathize. } \\
\text { - Learns to learn and think, } \\
\text { to self-organize. } \\
\text { - Develops its cultural } \\
\text { competences. Learns to } \\
\text { respect the differences of other } \\
\text { cultures and to understand } \\
\text { them. Respects the rights of } \\
\text { others and is able to combine } \\
\text { his rights and responsibilities. }\end{array}$ \\
\hline 4. & $\begin{array}{c}\text { - Collaborates } \\
\text { with pupils, helps }\end{array}$ & $\begin{array}{l}\text { - Able to create a pupil- } \\
\text { centred and problem- }\end{array}$ & $\begin{array}{l}\text { - Learns to develop its social } \\
\text { competences, work in a group, }\end{array}$ \\
\hline
\end{tabular}




\begin{tabular}{|c|c|c|c|}
\hline & $\begin{array}{l}\text { them to orient in the } \\
\text { media, directs their } \\
\text { work. }\end{array}$ & $\begin{array}{l}\text { centred atmosphere in the } \\
\text { classroom and serve it for } \\
\text { the self-organization and } \\
\text { personalization } \\
\text { learners, the recording of } \\
\text { learning outcomes and the } \\
\text { return to their activities. } \\
\text { - Teaches pupils to act } \\
\text { as media representatives } \\
\text { following the rules of the } \\
\text { latter and responding } \\
\text { appropriately } \\
\text { information coming from } \\
\text { the media. }\end{array}$ & $\begin{array}{l}\text { evaluate the results of its and } \\
\text { friends' work, to find the } \\
\text { information is needed on his } \\
\text { own, have own opinion, } \\
\text { communicate, conduct a } \\
\text { conversation. } \\
\text { - Learns to choose forms of } \\
\text { information dissemination and } \\
\text { creates media content based } \\
\text { on the needs of the recipient. } \\
\text { - Learns to understand } \\
\text { media information, to approach } \\
\text { content analytically } \\
\text { critically. } \\
\text { - Learns to understand the } \\
\text { author's value perceptions and } \\
\text { act cautiously. }\end{array}$ \\
\hline 5. & $\begin{array}{lr}\text { - Can } & \text { use } \\
\text { media technologies } \\
\text { to solve student } \\
\text { learning and } \\
\text { education problems, } \\
\text { organize integrated } \\
\text { lessons. }\end{array}$ & $\begin{array}{l}\text { - Knows how to } \\
\text { choose the information for } \\
\text { pupils that can be used in } \\
\text { classroom practice } \\
\text { (group, individual, self) } \\
\text { using different methods } \\
\text { (debate, conversation) } \\
\text { and using different } \\
\text { technologies (design, } \\
\text { problem training). } \\
\text { - When using media } \\
\text { tools, can use every type } \\
\text { of media according to } \\
\text { purpose, taking into } \\
\text { account both the } \\
\text { specificities of the subject } \\
\text { being taught and the tasks }\end{array}$ & $\begin{array}{l}\text { - Learns to learn, } \\
\text { independently find the } \\
\text { information he needs, } \\
\text { creatively approaches practical } \\
\text { and personal work, learns the } \\
\text { rules of debate, is able to build } \\
\text { electronic projects. } \\
\text { - Able to integrate } \\
\text { knowledge gained from various } \\
\text { disciplines, merform } \\
\text { appropriate } \\
\text { assignments at different stages } \\
\text { of the lesson, taking into } \\
\text { account national, cultural } \\
\text { contexts. }\end{array}$ \\
\hline
\end{tabular}




\begin{tabular}{|c|c|c|c|}
\hline & & $\begin{array}{l}\text { that pupils face and their } \\
\text { level of media literacy. } \\
\text { - Can use media } \\
\text { technologies to increase } \\
\text { the effectiveness of the } \\
\text { pedagogical process, the } \\
\text { motivation for pupil } \\
\text { learning and the } \\
\text { development of media } \\
\text { literacy. } \\
\text { - Uses } \\
\text { technologies at all stages } \\
\text { of the lesson. } \\
\text { - Able to teach students } \\
\text { to take into account } \\
\text { national, cultural-contexts } \\
\text { in media texts. Creates } \\
\text { situations where pupils } \\
\text { have to use and integrate } \\
\text { knowledge from other } \\
\text { disciplines. }\end{array}$ & \\
\hline 6. & $\begin{array}{l}\text { - Teaches } \\
\text { pupils to understand } \\
\text { the basic ideas of } \\
\text { media biographies, } \\
\text { media texts, to } \\
\text { discover contexts, to } \\
\text { feel and understand } \\
\text { the context of any } \\
\text { information, to test } \\
\text { its validity. }\end{array}$ & $\begin{array}{l}\text { - Discusses } \\
\text { information coming from } \\
\text { the media with pupils and } \\
\text { teaches them to analyze } \\
\text { it, formulate judgments } \\
\text { and conclusions, and } \\
\text { analyze. } \\
\text { - Teaches to draw } \\
\text { context and build their } \\
\text { own conclusions. } \\
\text { - Teaches to think } \\
\text { and to independently } \\
\text { verify the reliability of the }\end{array}$ & $\begin{array}{l}\text { - Learns to read and } \\
\text { analyze information, build own } \\
\text { opinion, check the reliability of } \\
\text { the information using other } \\
\text { sources, and make a report for } \\
\text { classmates. }\end{array}$ \\
\hline
\end{tabular}




\begin{tabular}{|c|c|c|c|}
\hline & & $\begin{array}{l}\text { necessary information } \\
\text { through other media } \\
\text { sources. } \\
\text { - Teaches to } \\
\text { understand the word of } \\
\text { media, to express own } \\
\text { ideas through the media, } \\
\text { to create, to give thematic } \\
\text { presentations at school. }\end{array}$ & \\
\hline 7. & $\begin{array}{l}\text { Regularly } \\
\text { monitors the impact } \\
\text { of the media on the } \\
\text { child and provides } \\
\text { feedback. }\end{array}$ & $\begin{array}{l}\text { - Able to study } \\
\text { pupils' media interests } \\
\text { through research } \\
\text { methods. } \\
\text { - Conducts surveys, } \\
\text { analyzes and using } \\
\text { parents' opinions. } \\
\text { - Makes corrections } \\
\text { based on the analysis of } \\
\text { the results of the studies } \\
\text { and the revealed data } \\
\text { informing parents and } \\
\text { pupils about them. }\end{array}$ & $\begin{array}{l}\text { - Shapes his own media } \\
\text { interests, performs reflection. } \\
\text { - Learns to create using } \\
\text { the terminology apparatus of } \\
\text { the genre according to age. } \\
\text { - Knows the rules of } \\
\text { etiquette, observes them in any } \\
\text { situation. }\end{array}$ \\
\hline 8. & $\begin{array}{l}\text { - Can use the } \\
\text { media during } \\
\text { extracurricular } \\
\text { activities and during } \\
\text { events. }\end{array}$ & $\begin{array}{l}\text { - Can use media } \\
\text { technologies in } \\
\text { extracurricular activities. } \\
\text { Uses opportunities for } \\
\text { excursions, Olympiads, } \\
\text { subject and other groups } \\
\text { to develop students' } \\
\text { creativity, independence } \\
\text { and initiative. } \\
\text { - Explores the } \\
\text { possibilities of a school } \\
\text { library as a media }\end{array}$ & $\begin{array}{l}\text { - Participates in school } \\
\text { excursions, subject and artistic } \\
\text { self-Olympiads uses the skills } \\
\text { of the extracurricular teams } \\
\text { and the skills they create to } \\
\text { create their own media and for } \\
\text { creativity } \\
\text { - Learns to use e-libraries } \\
\text { independently. }\end{array}$ \\
\hline
\end{tabular}




\begin{tabular}{|c|c|c|c|}
\hline & & $\begin{array}{l}\text { resource. } \\
\text { using it. } \\
\text { - With the help of } \\
\text { pupil's, it enriches the } \\
\text { school library's media } \\
\text { resources (collecting and } \\
\text { creating video films, } \\
\text { computer games, } \\
\text { electronic useful books), } \\
\text { organizes video and book } \\
\text { discussions with the } \\
\text { librarian, and so on. }\end{array}$ & \\
\hline 9. & $\begin{array}{l}\text { - Proficient in } \\
\text { Adobe animate, } \\
\text { Adobe voice, Adobe } \\
\text { Photoshop and } \\
\text { another computer, } \\
\text { instructional } \\
\text { software. }\end{array}$ & 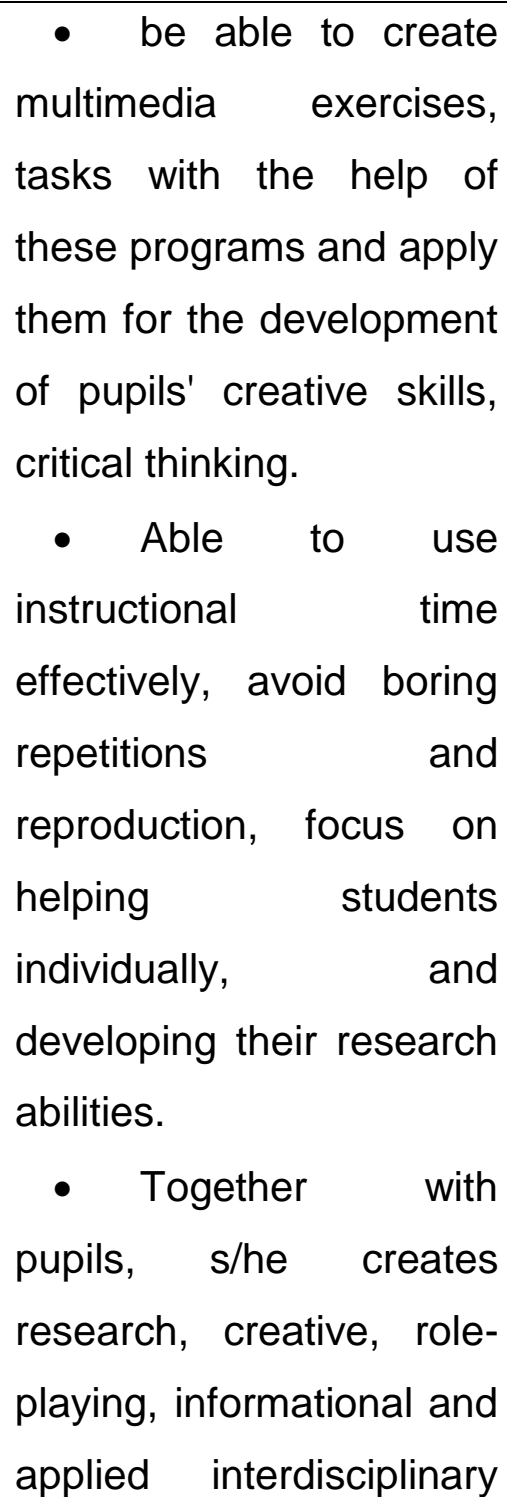 & $\begin{array}{l}\text { - Develops his linguistic, } \\
\text { learning competencies, } \\
\text { research abilities, learns to } \\
\text { create thematic projects. } \\
\text { - Learns to find electronic } \\
\text { resources for specific } \\
\text { purposes, participate in } \\
\text { discussions, and freely express } \\
\text { ideas about them. } \\
\text { - Learns to do electronic } \\
\text { exercises, find answers } \\
\text { quickly. }\end{array}$ \\
\hline
\end{tabular}




\begin{tabular}{|c|c|c|c|}
\hline & & media projects. & \\
\hline 10. & $\begin{array}{l}\text { - Engages in } \\
\text { parents' education } \\
\text { issues, contributing } \\
\text { to raising their level } \\
\text { of media literacy. }\end{array}$ & $\begin{array}{l}\text { - Able to effectively } \\
\text { transfer its media } \\
\text { knowledge to pupils' } \\
\text { parents. } \\
\text { - Involves parents in } \\
\text { all school activities, } \\
\text { particularly in media } \\
\text { literacy activities. } \\
\text { - Discuss } \\
\text { parents how to use the } \\
\text { media, find and use safe } \\
\text { forms, monitor child } \\
\text { activity, and prevent their } \\
\text { dependence on ICT. } \\
\text { - Knows and applies } \\
\text { forms of homework that } \\
\text { can help both parents and } \\
\text { pupils to increase media } \\
\text { literacy and reveal family } \\
\text { traditions and values. }\end{array}$ & $\begin{array}{l}\text { - Learns to discuss with } \\
\text { parents disturbing topics. } \\
\text { - Differentiates Internet } \\
\text { entertainment and its } \\
\text { developmental role. } \\
\text { - Learns to work with } \\
\text { parents and teachers to } \\
\text { achieve common goals. } \\
\text { - Performs self-control to } \\
\text { prevent its dependence on } \\
\text { ICTs and social alienation. } \\
\text { - }\end{array}$ \\
\hline
\end{tabular}

\section{Conclusions}

It is clear that we are not inclined to consider the characterization of the abovementioned competencies completed, time will definitely dictate its additions and adjustments. However, it is undeniable that a child's upbringing in any situation can not be effective if the teacher and parent do not cooperate, the school and the family do not complement each other, and most importantly, if the pupil does not become the subject of its own development. Therefore, when designing a teacher's media competences, it is necessary to base the child's interests, aspirations, and needs, give the child the opportunity to become a co-author of its own development and equip parents with the skills to help and support children in the process. Such an approach requires the current world events. Recent developments (social, environmental crises, epidemics and more) illustrate the role of information technologies and media in the modern human's life. And if in organizing a child's upbringing and education in the past, we would only value his or her social behaviour, the 
development of norms, and the ability to interact with people, then we also need to look at his communication, his own opinion and viewpoint, not being influenced by others, correctly predicting and projecting life's goals, the development of abilities to demonstrate independence, discipline, initiative, and creativity, the transfer of rules of netiquette. These challenges and demands of time can only be met by a teacher with such competences.

\section{References}

\section{Books}

Topuzyan A.O, Gyulamiryan J.H, Asatryan S.M, Poghosyan L.M, Karapetyan N.K, Avagyan L.M (2019) Media education in elementary school. Methodological handbook for teachers and parents. Yerevan, "Pedagogue" Publishing House, p.59-66.

Kubey, R. (1997) Media Education: Portraits of an Evolving Field. In: Kubey, R. (Ed.) Media Literacy in the Information Age. New Brunswick \& London: Transaction Publishers, p.2.

Tulodziecki, G. (1997) Medien in Erziehung und Bildung. Grundlagen und Beispiele einer handlungs und entwicklungsorientierten Medienpädagogik. Bad Heilbrunn, p.120.

Zmanovskaya N.V. (2004) Formirovanie media-kommunikativnoy obrazovannosti budushikh uchiteley.Avtoref.dis. kand. ped. nauk., Krasnoyarsk, P 24.

Fedorov A.V. and others (2005). Media Education. Mediaobrazovanie. Mediapedagogika. Mediaghurnalistika. CD M.: Programmi UNESCO «Informaciya dlya vsekh».

\section{Web Pages}

https://psyfactor.org/lib/fedorov14.htm 